\title{
Determinant of Initial Return of the Companies Doing Initial Public Offering on Indonesia Stock Exchange in 2014 - 2018
}

\author{
Yohanes Martinianus Rada ${ }^{1}$, Bambang Santosoe Marsoem., Ph. D ${ }^{2}$ \\ ${ }^{1}$ Master of Management, Mercubuana University, Jakarta, Indonesia \\ ${ }^{2}$ Lecturer of Postgraduate, Mercubuana University, Jakarta, Indonesia
}

\begin{abstract}
Initial return is a benefit or loss for investors because of the difference between purchased price of shares in the primary market with the selling price of the relevant shares in the secondary market. With this situation, investors can enjoy or dont get the return of the stock purchase. Thus study focus on Initial Return Positive that is benefit for investor. This study aimed to determine the effect of ROE, DER, Share Ownership, Underwriter Reputation and Firm Ages to the initial return on the IPO companies in the Indonesia Stock Exchange. Samples were selected of 55 from two sectors that list in Indonesia Stock Exchangethat that is Trade, Services \& Investment and Infrastructure, Utilities \& Transportation with a purposive sampling technique. The data gathered the financial statement on the IPO company prospectus in the period of 2014 to 2018 . The method of analysis used in this study is linear multiple regression analysis method. Result show that Underwriter Reputation partialy has signifikan effect on Initial Return. ROE, DER Share Ownership and Firm Age have effect to Initial Return.
\end{abstract}

Keyword:- Initial Return, DER, ROE, Share Ownership, Underwriter Reputation and Firm Age.

\section{INTRODUCTION}

The capital market is an alternative choice when companies want to get fresh funds for expansion and development. When a company decides to sell its shares to the public through a listing on the Indonesia Stock Exchange, the company conducts an Initial Public Offering (IPO) or initial public offering. The company's initial public offering of shares is called an IPO. In 2018 the number of companies conducting IPOs will increase significantly. At the beginning of November 2018, there were 50 listed companies listed on the Indonesia Stock Exchange (BEI) for 2018. This number would still increase and would be the record for listing of shares on the IDX most in a year since privatization in 1992 (Wareza, 2018). At the end of 2018, IDX listed as many as 55 companies conducting IPOs in 2018. For investors, IPO activities provide benefits because they get Initial Return or initial profit as a result of the purchase of IPO shares. Based on secondary data, the number of companies conducting IPOs and those providing Initial Returns that were processed by researchers shows that in 2014 there were 23 companies that did IPOs, 15 companies that gave positive Initial Returns (underpricing) with a percentage of $69.6 \%$ and 8 companies that gave Initials Negative return (overpricing) with a percentage of $30.4 \%$ and the highest number of movers in the Trade, Services and Investment (7) and Finance (8) sectors, each of which were 4 companies. For 2015 there were 16 companies that did IPO, 14 companies that gave positive Initial Return (underpricing) with a percentage of $67.5 \%$ and 2 companies that gave negative Initial Return (overpricing) with a percentage of $12.5 \%$ and the most number of moves in the Property, Real Estate and Building Construction sectors (6) as many as 5 companies. In 2016 there were 15 companies that carried out an IPO, 10 companies that gave positive Initial Returns with a percentage of $66.7 \%$ and 5 companies that gave negative Initial Returns (overpricing) with a percentage of $33.3 \%$ and the highest number of moves in the Trade sector, Services and Investment (7) and Trade, Services and Investment (9), each of which were 3 companies. For 2017 there were 37 companies that conducted IPOs, 26 companies that gave Initial Returns with a percentage of $73.3 \%$ and 11 companies that gave negative Initial Returns (overpricing) with a percentage of $29.7 \%$ and the highest number of movers in the Trade, Services sector and Investment (9) of 3 companies. For the year 2018 there were 55 companies doing IPOs, 50 companies are on Initial Return with a percentage of $90.9 \%$ and 5 companies that provide Initial Return negative with a percentage of $9.1 \%$ and the highest number of moves in the Trade, Services and Investa si (9) 18 companies. Based on these data the researcher wants to examine the factors that influence the company's Initial Return during the IPO namely Return on Equity (ROE), Debt to Equity Ratio (DER), Share Ownership, Reputation of underwriters and Firm Age. 
ROE Data of IPO companies in 2014 - 2018 in table 1 :

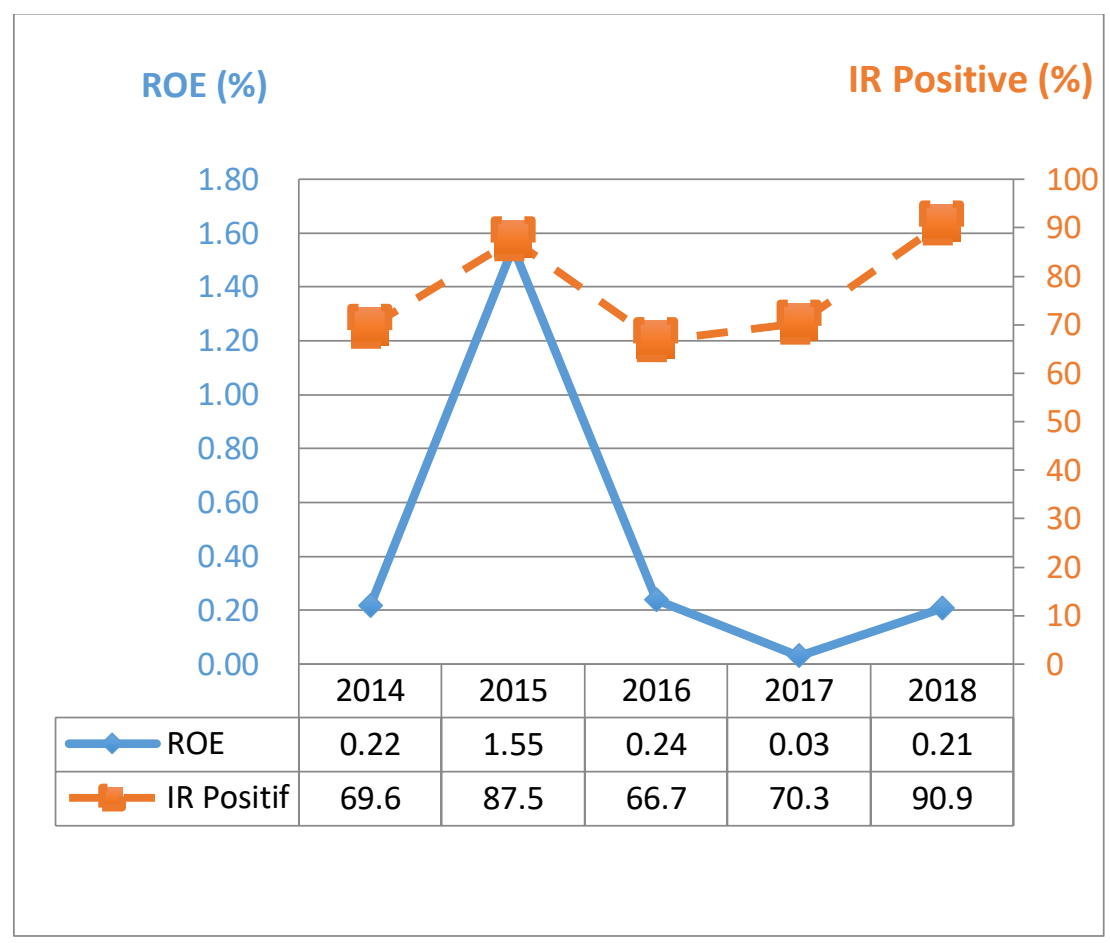

Table 1: - ROE Data of IPO Companies in 2014 - 2018

Source: Data processed by researchers (2020)

DER Data of IPO companies in 2014 - 2018 and the core value of return can be seen in the table 2.

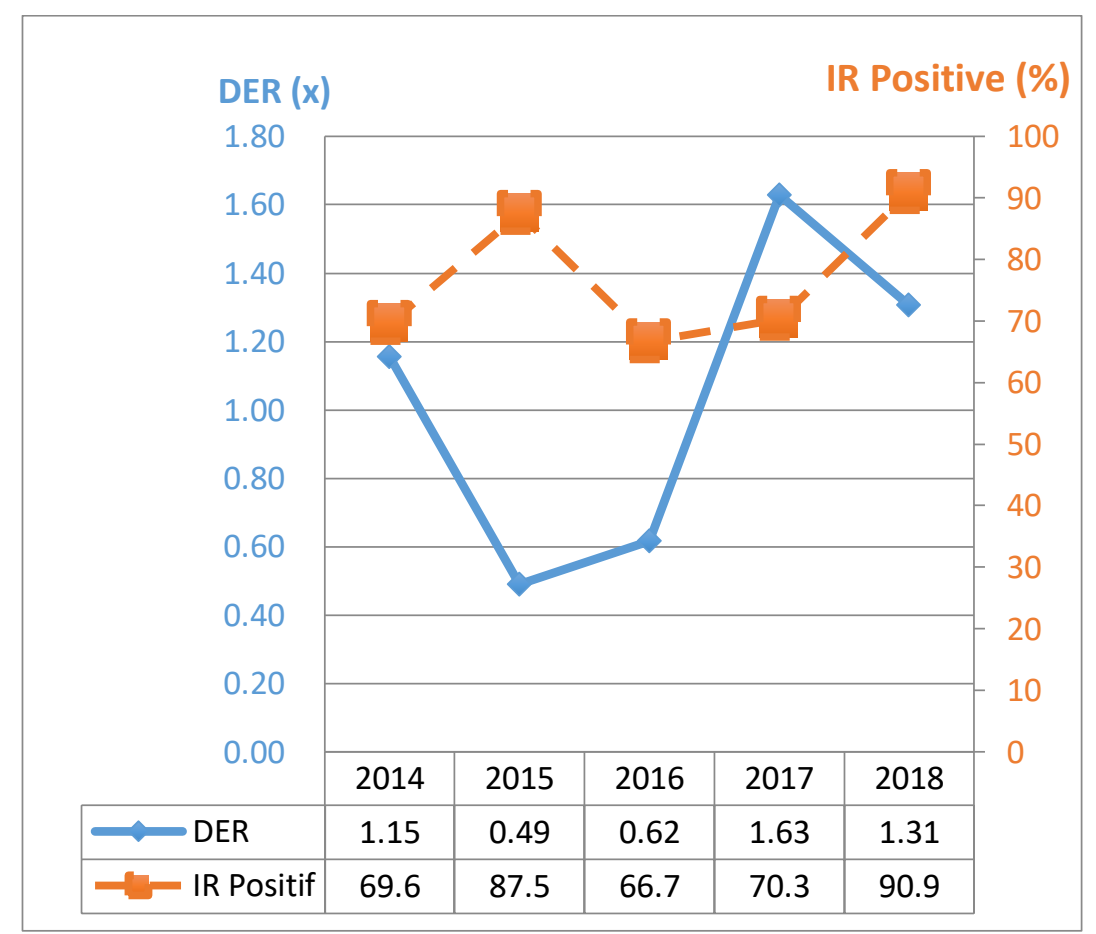

Table 2: - DER Data of IPO Companies in 2014 - 2018

Source: Data processed by researcher (2020) 
Data on Share Ownership of IPO Companies from 2014 to 2018 and the value of Initial Return can be seen in the table 3.

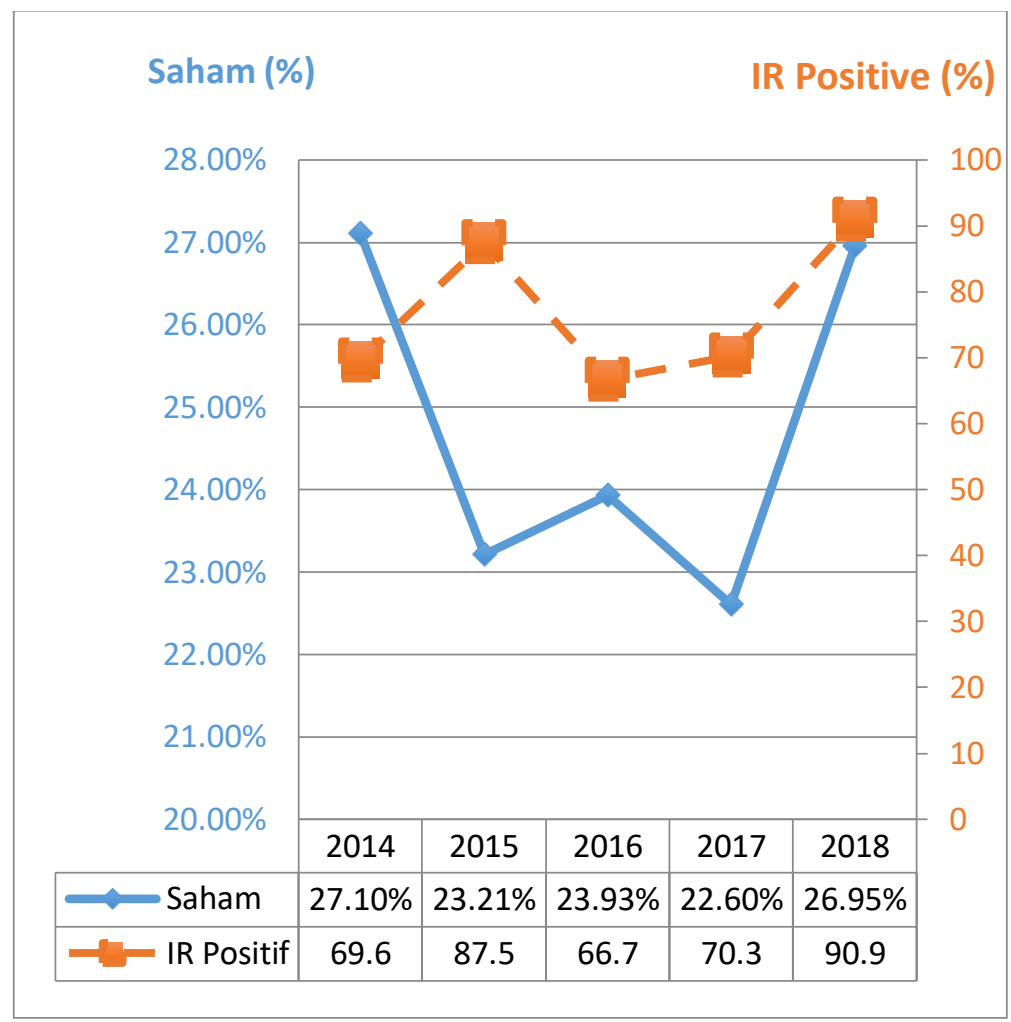

Table 3: - Share Ownership Data of IPO Companies 2014 - 2018 Source: Researcher processed data (2020)

Data Underwriters of IPO companies from 2014 to 2018 and the core value of returns can be seen in the table 4.

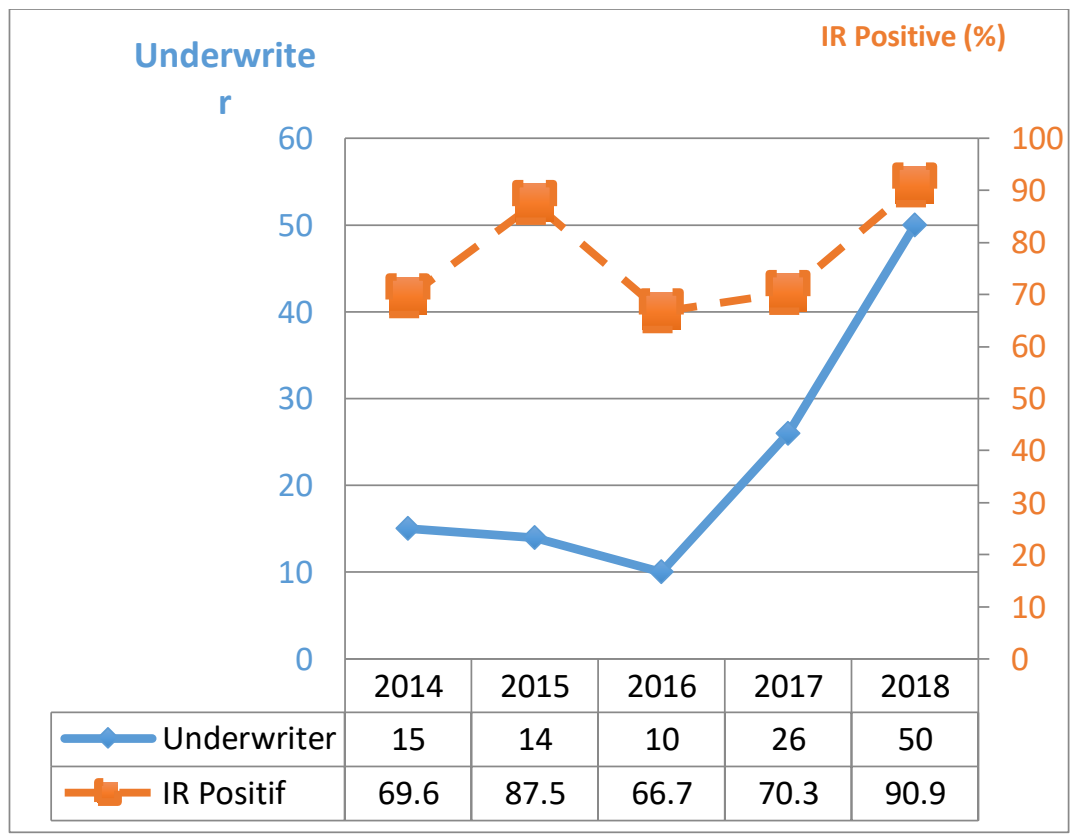

Table 4: - Underwriter Data of IPO Companies in 2014 - 2018 
Firm Age data of IPO Companies from 2014 to 2018 and the core value of returns can be seen in the table 5.

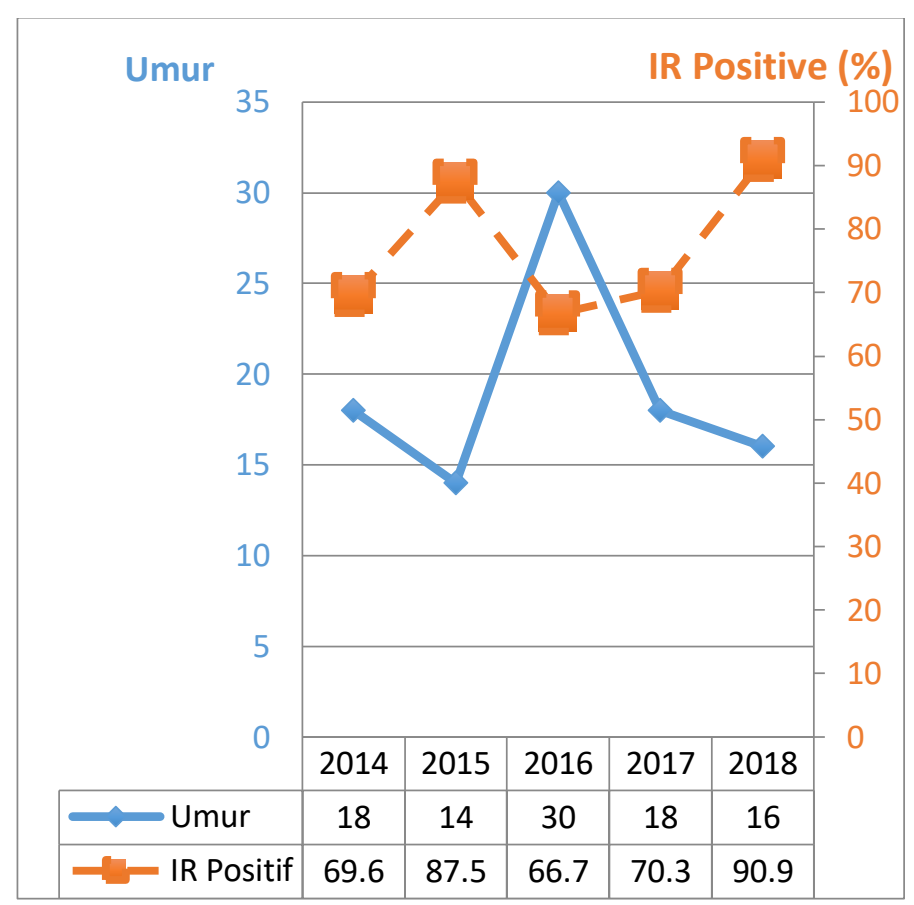

Table 5: - Firm Age Data IPO Companies in 2014 - 2018 Source: Data processed by researcher (2020) studies.

In addition, the gap phenomenon that is the background of this study is the difference in the results of research in previous

\begin{tabular}{|c|c|c|c|c|c|c|}
\hline No & Researcher and Year & ROE & DER & Shareholding & Underwriter Repurtation & Firm Age \\
\hline 1 & Aty Herawati, 2017 & (+) Significant & (+) Significant & & No effect & No effect \\
\hline 2 & Ali Albada, 2018 & & & & No effect & \\
\hline 3 & Khanna, 2012 & & & & & No effect \\
\hline 4 & Lutfianto, 2013 & & & No effect & & \\
\hline 5 & Wuryani, 2013 & No effect & & & & No effect \\
\hline 6 & Dark, 2009 & & & & & (+) Significant \\
\hline 7 & Indrasari, 2014 & & & No effect & No effect & \\
\hline 8 & Mad Gratitude, 2018 & & (-) Significant & & (-) Significant & No effect \\
\hline 9 & Lowry, 2010 & & & & & (+) Significant \\
\hline 10 & Kurniawan, 2007 & & No effect & (+) Significant & No effect & \\
\hline 11 & Sidarta Hermin, 2015 & (-) Significant & & & (-) Significant & No effect \\
\hline 12 & Adel Boubaker, 2011 & & & & & (+) Significant \\
\hline 13 & Haryanto, 2017 & & No effect & (-) Significant & & \\
\hline 14 & Song, 2014 & & & & (+) Significant & \\
\hline 15 & Chen Su, 2011 & & & & (+) Significant & \\
\hline
\end{tabular}


ISSN No:-2456-2165

\begin{tabular}{|c|c|c|c|c|c|c|}
\hline 16 & Hastuti, 2017 & & & & No effect & No effect \\
\hline 17 & Widyawati, 2019 & No effect & No effect & & No effect & \\
\hline 18 & Yuliani, 2019 & (-) Significant & & & (-) Significant & \\
\hline 19 & Wei Leong, 2015 & & & & (-) Significant & (-) Significant \\
\hline 20 & Sudjiman, 2019 & No effect & No effect & No effect & & \\
\hline 21 & Rivandi, 2013 & (+) Significant & No effect & & & \\
\hline 22 & Wiguna, 2013 & & (+) Significant & & No effect & No effect \\
\hline 23 & Wijayanto, 2010 & & No effect & (-) Significant & & \\
\hline 24 & Marlius, 2019 & & No effect & & & \\
\hline 25 & Ariska, 2015 & & & (-) Significant & & \\
\hline 26 & Widyarti, 2013 & & No effect & & & \\
\hline 27 & Baba, 2019 & & & (+) Significant & & \\
\hline 28 & Hidayati, 2020 & & No effect & & (-) Significant & No effect \\
\hline 39 & Wasiuzzaman, 2018 & & & & & No effect \\
\hline 30 & Zuliardi, 2020 & & No effect & No effect & & (-) Significant \\
\hline
\end{tabular}

Table 6: -. Research Gap

Source: Researcher processed data (2020)

With the above phenomenon, the researcher wants to examine the effect of ROE, DER, Share Ownership, Underwriter Reputation and Firm age on the Initial Return of the company conducting Initial Public Offerings (IPO). Based on the description above, the writer takes the title" Determinant Initial Return Of The Companies Doing Initial Public Offering On The Indonesia Stock Exchange In 2014 - 2018 ".

\section{THEORETICAL REVIEW}

\section{A. Initial Public Offering}

Initial Public Offering or IPO (Thionita, 2019) is a stock of a company which is first released to be sold to the public or public, so that shares are no longer privately owned. There are several reasons why a company conducts an IPO:

$>$ Get Additional Capital

$>$ Accelerating Company Growth

$>$ Increase the Overall Value of the Company

$>$ Improve Company Image

\section{B. Initial Return}

According to Lutfianto (2013) Initial Return is the profit gained by shareholders because the difference in the price of shares purchased in the primary market is smaller than the selling price of the shares concerned in the secondary market. The owners of the company want to minimize the situation of underpricing, because the occurrence of underpricing will cause a transfer of prosperity from the owner to the investors because the investors enjoy Initial Return.

\section{Return on Equity (ROE)}

According to Kurniawan (2007) Return On Equity or ROE is one of the profitability ratios. This ratio measures the ability of companies to generate profits based on certain share capital. ROE is used to measure the effectiveness of the company in generating profits by utilizing existing stock capital. ROE is a measure of profitability from the perspective of shareholders.

\section{Debt to Equity Ratio (DER)}

According to Erlina (2013), Debt to Equity Ratio or DER is one of the leverage ratios that reflects the company's ability to meet all its obligations as indicated by several parts of the capital used to pay off or pay off debt. DER has a positive effect on the core return because theoretically DER shows the risk of a company so that it impacts on uncertainty (Suyatmin and Sujadi, 2006).

\section{E. Share Ownership}

The number of shares offered reflects the share ownership information by the issuer that will be used by investors as a measure of whether or not the company's performance is good. The greater the percentage of shares offered, the better the stock's performance or the more liquid to trade. A liquid stock is a sign that the stock has the potential to go up so that it draws a lot of investors' attention to buy it (Lutfianto, 2013). The amount of shares 
offered to the public or the general public shows how much of the paid up capital the public will have.

\section{F. Underwiter reputation}

Underwriter reputation (Herawati, 2017) is called an underwriter that functions to offer shares in the secondary market to investors. Companies that go public usually do not know the stock market share in the stock market. This ignorance shows how companies use underwriters as underwriters of their shares on the stock exchange. The underwriter's reputation is considered by investors when they invest. To avoid risk, Underwriters want a low price.

However, underwriters with high reputation usually have a tendency to dare to give high prices. A high price means that it will reduce the level of Initial Return.

\section{G. Firm Age}

According to Kurniawan (2007), firm age is an important part for investors to consider when investing. The age of the issuer company shows how long the company is able to survive and is proof that the company is able to compete and can take the business opportunities that exist in the economy. Companies that operate longer have greater ability to provide company information that is more extensive and broader than what has just been established. Firm age is calculated by reducing the offering year at the IPO with the year when the company was established.

\section{H. Prior Research}

Research conducted Aty (2017) who find that ROE and DER significant effect on the Initial Return. Research by Kurniawan (2007) found that share ownership has a significant effect on Initial Return. Song's research (2014) found that the Underwriter's reputation had a significant effect on Initial Return . Research by Adel Boubaker (2011) found that firm age had a significant effect on Initial Return

\section{Conceptual Framework}

The research framework in this paper is as follows

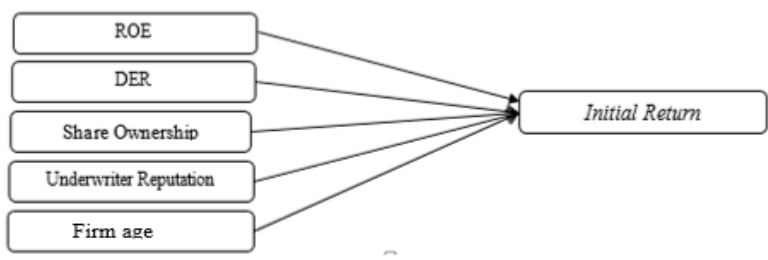

Fig 1:- Thinking Framework

\section{J. Hypothesis}

Based on the framework that has been dikemu ka kan, the research hypothesis can be formulated as follows:

$>$ H1: ROE has an influence on Initial Return

$>$ H2: DER has an influence on Initial Return

$>$ H3: Share Ownership has an influence on Initial Return.

$>$ H4: Underwriter reputation has an influence on Initial Return

$>$ H5: Firm Age has an influence on Initial Return

\section{METHODOLOGY}

\section{A. Population and Sample}

The population in this study are companies that did Initial Public Offering on the Indonesia Stock Exchange in 2014 - 2018 as many as 146 companies. Sampling of this population was conducted using purposive sampling and the sample was random ( non-probability sampling ). The sample criteria specified are:

$>$ IPO Companies in $2014-2018$

$>$ The company's shares do not experience overpricing.

$>$ Companies from the Infrastructure, Utilities and Transportation sectors.

$>$ Companies from the Trade, Services and Investment sectors.

$>$ Initial Return Value $>0$

The sample of this study after being calculated based on the criteria used were 55 companies.

\section{B. Data Collection Methods}

Data collection methods used in this study are documentation and literature. The data used in this study are prospectus data of companies conducting IPOs from 2014 to 2018 . This data was obtained from several official financial sites including the Jakarta Stock Exchange official sites namely idx.co.id, finance.yahoo.com and investing. com. Besides that, other sources of references that support this research are also used, such as journals and other internet sources that are related and support this research.

\section{Data Analysis Methods}

The data analysis method used in this study includes descriptive statistics, classic assumption tests, multiple regression analysis and hypothesis testing.

\section{RESULTS AND DISCUSSION}

\section{* Statistical Descriptive Analysis}

\section{A. Initial Return}

On the results of statistical descriptive analysis of variables Initial Return shows the highest value and the lowest value of the variable Initial Return changes from year to year during 2014 - 2018. For the highest value for each year by $50,40,70,70$ and 76 . For values terenda $h$ each year at $3: 33,8: 57,1: 54,13: 39$ and 0.43 . the highest score for a five-year study was in 2018 with a value of 76 yai tu PT. Royal Prima Tbk and the lowest score in 2018 with the lowest score of 0.43 is PT Gihon Telekomunikasi Indonesia Tbk . The average value of the variable Initial Return shows motion fluctuate on companies that do an IPO in 2014 - 2018. In 2015, a decline but rose in 2016 and 2017 and fell back in the year 2018. Of this average can be seen that for years 2014 to 2018 Initial Return moves in the 24 to 52 point range 


\section{B. $R O E$}

In the results of the descriptive statistical analysis of the ROE variable, it shows the highest and lowest values for the ROE variable in 2014 - 2018 experiencing changes every year. The highest scores for each year were $0.3,0.2$, $0.69,0.16$ and 1.52 , respectively. The lowest values for each year were $-0.09,0.08,-0.13,-0.35$ and -0.12 , respectively. Overall, the highest value for the ROE variable in 2014 - 2018 was 1.52, namely PT Yelooo Integra Datanet Tbk and the lowest value of -0.35 , namely PT Marga Abhinaya Abadi Tbk. The average ROE value in 2014 was 0.13 and increased respectively in the following two years, namely 2015 and 2016 amounting to 0.16 and 0.2 . In 2017 the average ROE value decreased to -0.021 , but increased to 0.22 in the following year. This shows that there is an increase in net profit every year and a significant increase occurred in 2018.

\section{DER}

The results of the descriptive statistical analysis of the DER variable show that the highest and lowest values for the DER variable in 2014-2018 have changed every year. The highest scores for each year were 2.72, 0.83, 2, 5.52 and 3.45 respectively. The lowest values for each year are $0.01,0.02,0.08,0.03$ and 0.05 , respectively. The lowest value for the DER variable did not change significantly. The values are in the range $0.08-0.01(8 \%-1 \%)$. The highest value for the DER variable is still at a fairly high level, especially for 2014 (2.72), 2016 (2) 2017 (5.52) and 2018 (3.45). The level of risk for the four years above is still at a high enough level. Overall, the highest value for the DER variable is 5.52, namely PT Marga Abhinaya Abadi Tbk and the lowest value is 0.08, namely Prodia Widyahusada, Tbk. the average DER value in 2014 - 201 has changed every year. In 2014 - 2016 the average DER value was in the range $0.42-0.86$. For the years 20 and 2018 it is in the range $1.28-1.44$. These results indicate that the average level of risk for companies conducting IPOs from the two sectors studied has decreased.

\section{Share Ownership}

The results of the descriptive statistical analysis of the share ownership variable show that the highest and lowest values for the Share Ownership variable in 2014 - 2018 have changed every year. The highest scores for each year were $31.24 \%, 44.12 \%, 47.37 \%, 35.89$ and $52 \%$. The lowest values for each year were $10 \%, 18 \%, 10 \%, 1.02 \%$ and $13.92 \%$ respectively. The highest value or the largest percentage of shares offered each year from 2014 to 2018 is in the range of $31 \%-52 \%$. The lowest value or smallest number of shares traded is in the range of $1 \%-13 \%$. For the largest (highest) shares traded during 2014 to 2018 amounting to 52\%, namely PT Satria Antaran Prima Tbk. For the smallest (lowest) shares traded during 2014 to 2018 amounting to $1.02 \%$, namely PT MAP Boga Adiperkasa Tbk. the average value of the Share Ownership variable from 2014 to 2018 has changed every year but is in the $20 \%$ range. This shows that the average shares traded at the time of the IPO were $20 \%$ of the total $100 \%$ shares owned by the company.

\section{E. Firm Age}

In the results of the descriptive statistical analysis, the variable firm age shows the highest and lowest values for the variable age of the company in 2014 - 2018 which changes every year. The highest scores for each year were 18, 20, 29, 31 and 40 respectively. The lowest scores for each year were 4, 3, 5, 2 and 2 respectively. The highest score (age of the oldest company) for the years 2014 to 2018 for 40 years, namely PT Surya Pertiwi Tbk. And for the lowest value (youngest company age) of 2 years, namely PT Yelooo Integra Datanet Tbk and PT Kioson Commercial Indonesia, Tbk. The average age of the company during 2014 to 2018 is in the range of $10-20$ years. The average age of a company in the range of 10-20 years is considered old enough and is considered sufficiently experienced.

\section{F. Underwriter Reputation}

Based on a sample of 55 companies, the results of statistical descriptive analysis can be seen that the number of e partners who use Underwriters who are included in the top 10 most active Underwriters is greater $(58, \%$, or 32 issuers) than issuers that use Underwriters outside the last 10 ( $42 \%$ or 23 issuers).

\section{* Classical} Assumption

A. Normality Test

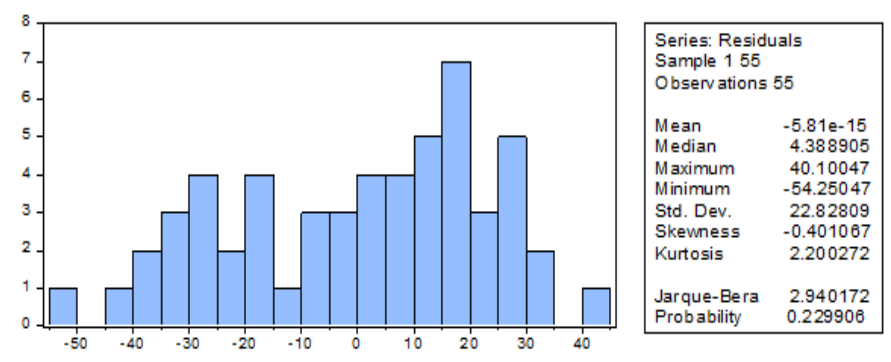

Fig 2:- Normality of the Jarque Method Test Results Source: Researcher processed data (2020)

Based on Fig 2, it is obtained that the JB value is 2.94 and the p value is $0.22(22 \%)$ while for the Chi Square value by looking at the value of the number of independent variables as much as 5 and with a significance of 0.05 , the Chi Square table value is 11.07 . . From these results it was found that the JB value is smaller than the Chi Square table value $(2.94<11.07)$, so it can be concluded that the residual data in this study is normally distributed.

\section{B. Multicollinearity Test Results}

The results of the multicollinearity test with the Eviews 10 program can be seen in table 4.8 above. From the table, it can be seen that the Centered VIF value for the five independent research variables is less than 10. The ROE variable is 1.074, the DER is 1.15, the Share Percentage is 1.13, the Underwriter's Reputation is 1.02 and the firm Age is 1.05. Based on these results, the conclusion is that the regression model does not occur multicollinearity problems. 


\section{Heteroscedasticity Test}

From the results of the heteroscedasticity test in Table 4.9 using the Glejser method, the prob value for each independent variable is greater than $0.05(5 \%)$. The ROE variable is $0.6085(60.85 \%)$, DER is $0.8186(81.86 \%)$ The share percentage is $0.1734(17.34 \%)$ The Underwriter's reputation is $0.8559(86.9 \%)$ and the age of the company is $0.5899(58.99 \%)$. Based on these results, it can be concluded that there are no symptoms of heteroscedasticity in this research model.

\section{Autocorrelation Test}

Durbin Watson value obtained by $2.12>1.12$. Whereas from the DW table with a significance of 0.05 and the amount of data $(\mathrm{n})=55$, and $\mathrm{k}=5(\mathrm{k}$ is the number of independent variables), the $\mathrm{dL}$ value is 1.374 and $\mathrm{dU}$ is 1.768 (so it can be calculated that 4-dU is 2,232 and 4- dL is 2,626. Because the DW value is between $\mathrm{dU}$ and 4-dU, there is no autocorrelation problem..

\section{* Model Test \\ A. F test}

\begin{tabular}{lrll}
\hline \hline & & & \\
R-squared & 0.204132 & Mean dependent var & 42.14964 \\
Adjusted R-squared & 0.122921 & S.D. dependent var & 25.58875 \\
S.E. of regression & 23.96450 & Akaike info criterion & 9.293693 \\
Sum squared resid & 28140.56 & Schwarzcriterion & 9.512675 \\
Log likelihood & -249.5766 & Hannan-Quinn criter. & 9.378375 \\
F-statis tic & 2.513607 & Durbin-Watson stat & 2.122744 \\
Prob(F-s tatis tic) & 0.041994 & & \\
\hline \hline
\end{tabular}

Table 7: - Test results F

Source: Researcher processed data (2020)

Based on table 7, the results of the Eviews calculation, it is obtained that F count is 2.51. Meanwhile, the Ftable value obtained for Ftable was 2.40. The value of $F$ count $>F$ table $(2.51>2.40)$, then Ho is rejected, meaning that ROE, DER, Share Ownership, Underwriter Reputation and firm Age jointly affect the Initial Return of companies conducting IPOs from 2004 to 2018. the value of the significance level of the variables ROE, DER, Share Ownership , Underwriter Reputation and Company Age is $0.04<0.05$, which means that $\mathrm{H} 0$ is rejected. Thus it can be concluded that there is a significant influence between the independent variable on the dependent variable.

\section{B. Determination Coefficient Analysis}

\begin{tabular}{lrll}
\hline \hline & & & \\
R-squared & 0.204132 & Mean dependent var & $42.14 \AA$ \\
Adjusted R-squared & 0.122921 & S.D. dependent var & $25.58 \varepsilon$ \\
S.E. of regression & 23.96450 & Akaike info criterion & $9.293 \epsilon$ \\
Sum squared resid & 28140.56 & Schwarz criterion & $9.512 \epsilon$ \\
Log likelihood & -249.5766 & Hannan-Quinn criter. & $9.378 \AA$ \\
F-statis tic & 2.513607 & Durbin-Wats on stat & $2.122 i$ \\
Prob(F-statistic) & 0.041994 & & \\
\hline \hline
\end{tabular}

Table 8:- Results of the Determination Coefficient Analysis Source: Researcher processed data (2020)

Based on Table 8 obtained value R 2 of 0.204 $(20.4 \%)$. This shows that the variation of the independent variables used in the model ( ROE, DER, Share Ownership,
Underwriter Reputation and Firm Age ) is able to explain $20.4 \%$ of variations in Initial Return variables, while the rest is explained by other variables not included in this research model.

\section{Multiple Linear Regression Coefficient Test}

\begin{tabular}{|c|c|c|c|c|}
\hline Variable & Coefficient & Std. Error & t-Statistic & Prob. \\
\hline C & -10.74058 & 10.69911 & -1.003876 & 0.3204 \\
\hline ROE & -1.192879 & 2.960990 & -0.402865 & 0.6888 \\
\hline DER & 57.57006 & 32.72778 & 1.759058 & 0.0848 \\
\hline Share ownership & 17.04805 & 6.636506 & 2.568829 & 0.0133 \\
\hline Underwriter & -0.386360 & 0.339335 & -1.138579 & 0.2604 \\
\hline Firm Age & 25.76159 & 12.27379 & 2.098912 & 0.0410 \\
\hline
\end{tabular}

Table 9:- Results of Multiple Linear Regression Analysis Source: Researcher processed data (2020)

Based on table 9 , it can be seen and obtained the regression equation model as follows:

$\mathrm{IR}=25.76$ - 10.74ROE - 1.19DER + 57.57 Shares + 17.04RU - 0.38UP + e

Meaning:

$>$ The constant is 25.76. If the independent variable (ROE DER, Share Ownership, Underwriter Reputation and firm Age) is 0 , then the Initial Return value is 25.76 .

$>$ The ROE variable regression coefficient (X1) is 10.74. If the other independent variables (DER, Share Ownership, Underwriter Reputation and firm Age) are fixed in value and ROE increases by $1 \%$, then the Initial Return (Y) will decrease by 10.74.

The DER Variable Regression Coefficient (X2) is 1.19. If the other independent variables (ROE, Share Ownership, Underwriter Reputation and Company Age) are fixed in value and DER increases by $1 \%$, then Initial Return (Y) will also increase by 1.19.

$>$ The Share Ownership Variable Regression Coefficient (X3) is worth 57.57. If the other independent variables (ROE, DER, Underwriter Reputation and firm Age) are fixed in value and the Share Ownership Percentage increases by $1 \%$, the Initial Return (Y) will also increase by 57.57 .

$>$ The Underwriter's Reputation Variable Regression Coefficient (X4) is 17.04. If the other independent variables (ROE, DER, Share Ownership and firm Age) are fixed in value and the Underwriter's Reputation increases by $1 \%$, then the Initial Return (Y) will also increase by 17.04 .

$>$ Firm Age Variable Regression Coefficient (X5) is 0.38. If the other independent variables (ROE, DER, Share Ownership and Underwriter's Reputation) are fixed in value and the Firm Age increases by $1 \%$, then the Initial Return (Y) will also decrease by 0.38 . 


\section{Test T}

Based on the $\mathrm{t}$ table and the calculated $\mathrm{t}$ value, conclusions are made based on the testing criteria, namely as follows:

\section{$>$ ROE (Return on Equity)}

Partially, ROE has no effect on the Initial Return of companies conducting IPOs from 2014 to 2018. This can be seen through the value of tcount <ttable $(-1.003<2.009)$, so H0 is accepted. It can be concluded that ROE (Return on Equity) partially has no effect on Initial Return. An increase or decrease in the ROE value does not change the Initial Return value. If the ROE value increases or decreases by $1 \%$, the Initial Return value remains the same or does not change.

\section{$>\operatorname{DER}$ (Debt Equity Ratio)}

Partially, DER has no effect on the Initial Return of companies conducting IPOs from 2014 to 2018. This can be seen through the value of tcount $<$ ttable $(-0.402<2.009)$, so H0 is accepted. It can be concluded that the DER (Debt Equity Ratio) partially has no effect on Initial Return. An increase or decrease in the DER value does not change the Initial Return value. If the DER value increases or decreases by $1 \%$, the Initial Return value remains the same or does not change.

\section{$>$ Shareholding}

Partially, Share Ownership has no effect on the Initial Return of companies conducting IPOs from 2014 to 2018. This can be seen from the value of tcount <ttable $(1.759$ $<2.009$ ), then H0 is accepted. It can be concluded that the share ownership percentage partially has no effect on Initial Return. An increase or decrease in the value of Share Ownership does not change the value of Initial Return. If the Share Ownership Percentage value increases or decreases by $1 \%$, the Initial Return value remains the same or does not change.

\section{$>$ Underwriter's reputation}

Partially, the Underwriter's Reputation has an effect on the Initial Returns of companies conducting IPOs from 2014 to 2018. This can be seen from the value of tcount> ttable (2.56> 2.009), so H0 is rejected and it can be concluded that the Underwriter's Reputation partially affects the Initial. Return.

\section{> Firm Age}

Partially, firm age has no effect on the Initial Return of companies conducting IPOs from 2014 to 2018. This can be seen through the value of tcount <ttable $(-1.13<2.009)$, so $\mathrm{H} 0$ is accepted. It can be concluded that the company's Pumur partially has no effect on Initial Return . An increase or decrease in firm Age value does not change the Initial Return value. If firm Age value increases or decreases by $1 \%$, the Initial Return value remains the same or does not change.

\section{* Discussion}

\section{A. Effect of Return on Equity (ROE) on Initial Return}

Return on Equity (ROE) has no partial effect on the Initial Return of companies conducting IPOs in 2014 - 2018 at a $5 \%$ significance level. The $\mathrm{p}$ value for ROE is $0.32>$ 0.05 which indicates that ROE has no effect on Initial Return. The results of this study indicate that ROE does not provide positive or negative signals to investors when making decisions related to purchasing shares in the primary market (IPO). The initial hypothesis built is that ROE has an influence on Initial Return. Based on the results of this study, this hypothesis is rejected. ROE has no effect on Initial Return. . Based on the results of this study, this hypothesis is rejected. ROE has no effect on Initial Return .The results of this study contradict the research conducted by Aty (2017) and Rivandi (2013), who stated that ROE has a significant positive effect on Initial Return. The results of this study support research conducted by Widyawati (2019), Sudjiman (2019) and Wuryani (2013) who stated that ROE has no influence on the Initial Return.

\section{B. Effect of Debt Equity Ratio (DER) on Initial Return}

The Debt Equity Ratio (DER) has no partial effect on the Initial Return of companies conducting IPOs in 2014 2018 at a significance level of $5 \%$. The $p$ value for DER is 0.68> 0.05 which indicates that DER has no effect on Initial Return. A high DER value indicates the financial risk or risk of the company's failure to repay the loan. Conversely, if the DER value is small, the financial risk or risk of failure to repay the loan is small. The results of this study indicate that DER information is not a major consideration for investors when buying shares that conduct an IPO. The initial hypothesis built is that DER has an influence on Initial Return. Based on the results of this study, this hypothesis is rejected. DER has no effect on Initial Return. The results of this study contradict research conducted by Aty (2017) and Wiguna (2013) which states that DER has a significant positive effect on Initial Return . The results of this study contradict the research conducted by Aty (2017) and Wiguna (2013) which stated that DER had a significant positive effect on Initial Return. The results of this study support research conducted by Widyawati (2019), Sudjiman (2019), Marlius (2019), Haryanto (2017) and Rivandi (2013) which states that DER has no effect on Initial Return. Increase or decrease in DER value does not affect the increase or decrease in Initial Return value. Value Initial Return remains the same or unchanged.

\section{Effect of Share Ownership on Initial Return}

Share ownership does not have a partial effect on the Initial Returns of companies conducting IPOs in 2014 2018 at a significance level of 5\%. The $\mathrm{p}$ value for Share Ownership is 0.08> 0.05 which indicates that Share Ownership has no effect on Initial Return. The percentage of shares offered reflects share ownership information where this information will be used by investors to see and assess the company's prospects whether it is in stable condition or not. The high demand for stocks will cause the 
stock price to increase and will certainly result in an Initial Return . The initial hypothesis built is that share ownership has an influence on Initial Return. Based on the results of this study, this hypothesis is rejected. Share Ownership has no effect on Initial Return .. The results of this study support research conducted by Sudjiman (2019), Indrasari (2014) and Lutfianto (2013) which states that the Percentage of Share Ownership has no effect on Initial Return. Increase or decrease in value Percentage of Share Ownership does not bring changes to the increase or decrease in value of Initial Return. Value Initial Return will remain the same or unchanged.

\section{Effect of Underwriter Reputation on Initial Return}

Underwriter's reputation has a partial effect on the Initial Return of companies conducting IPOs in 2014-2018 at a significance level of 5\%. The p value for Underwriter's Reputation is $0.01<0.05$, which indicates that Underwriter's Reputation has a significant positive effect on Initial Returns. The results of this study contradict the results by Song (2014) sthat the reputation of the Underwriter has effect on Initial Return. However, research shows different results that differ from research conducted by Yuliani (2019); Mahatidana (2017), Leong (2015) stated that the Underwriter's reputation had a significant negative effect on Initial Return .

\section{E. Effect of Firm Age on Initial Return}

Firm age partially has no effect on the Initial Return of companies conducting IPOs in 2014 - 2018 at a significance level of $5 \%$. The $\mathrm{p}$ value for firm age is $0.26>$ 0.05 which indicates that firm age has no effect on initial returns. firm Age shows how long the company can survive and proves that they can compete and take business opportunities. The initial hypothesis built is that company age has an influence on Initial Return. Based on the results of this study, this hypothesis is rejected. firm age has no effect on Initial Return. Information on firm age is not a major consideration for investors when buying shares in companies conducting an IPO.The results of this study contradict the results of research conducted by Dark (2009), Lowry (2010) and Baubaker (2011) which stated that Firm Age had a significant positive effect on Initial Return. The results of this study support the research conducted by Aty (2017), Syukur (2018), Hermin (2015), Hastuti (2017), Mahatidana (2017) and Wiguna (2013) which state that the firm age has no effect on the Initial Return. Increase or decrease in value of firm Age does not change the value of Initial Return. Value Initial Return will remain the same or unchanged although the value of Age were changed.

\section{CONCLUSIONS AND SUGGESTION}

\section{A. Conclusion}

$>$ ROE has no effect on Initial Return at a significance level of $0.05(5 \%)$. These results reject the effect of ROE on Initial Return which has been hypothesized which states that ROE has an effect on Initial Return . ROE has no effect on Initial Return .

$>$ DER has no effect on Initial Return at a significance level of $0.05(5 \%)$. These results reject the effect of
DER on Initial Return which has been hypothesized which states that DER has an effect on Initial Return. DER has no effect on Initial Return .

$>$ Share Ownership has no effect on Initial Return at a significance level of $0.05(5 \%)$. These results reject the effect of Share Ownership on Initial Return which has been hypothesized which states that Share Ownership Percentage affects Initial Return . Share Ownership has no effect on Initial Return .

$>$ Underwriter's reputation has a significant positive effect on Initial Return. The results of the analysis show that the value of the Underwriter's Reputation tcount is greater than the t-table value, which means that the Underwriter's Reputation has an effect on the Initial Return. The results of this study confirm the hypothesis that has been made which states that the Underwriter's Reputation has an effect on Initial Returns.

$>$ Company age has no effect on Initial Return at a significance level of $0.05(5 \%)$. These results reject the effect of company age on Initial Return which has been hypothesized which states that company age has an effect on Initial Return.

\section{B. Suggestion}

\section{$>$ Theoretical Suggestions}

- Find and examine other financial variables that are not used in this study.

- Using other non-financial variables that are not used in this study. In addition, it can also use one type of factor, both financial and non-financial in subsequent research.

- Using samples from other sectors not included in this study. Addition of sectors will help the accuracy of the influence given to Initial Return.

- Add a number of samples to examine the effect of the dependent variable on Initial Return. The more samples studied will help find the strength or weakness of the effect given by the independent variable on Initial Return.

\section{$>$ Practical Suggestions}

- Suggestions for Issuers

Companies that will conduct an IPO need to pay proper attention and make the right decisions regarding the underwriter who will be the underwriter of the company. Companies that will conduct IPOs or issuers need to improve the performance of their companies to be able to attract investors to buy shares of the company.

\section{- Advice for Investors}

Suggestions for investors that information relating to ROE, DER, the number of shares offered and firm age are not the only information for buying company shares that are conducting an IPO.

$\checkmark$ For companies, it is necessary to improve the performance and rating of bonds to maintain investor confidence. In addition, the company also needs to increase its total assets to make it easier to find external funding sources through debt or bond issuance. That is 
because both of them are proven to have an effect on YTM of corporate bonds.

$\checkmark \quad$ For investors and prospective investors to pay more attention to the company's annual report and the company's ongoing report as a consideration in investing.

\section{REFERENCES}

[1]. Baba, B \& Sevil, G 2019, 'Predicting Ipo Initial Returns Using Random Forest', Journal Pre-proof Borsa istanbul Review, vol. 20, issue 1 pp: 13 - 23

[2]. Boubaker, A 2011, 'Determinants of the Components of IPO Initial Returns: Paris Stock Exchange', International Journal of Accounting and Financial Reporting, vol. 1, no. 1, pp. 190 - 211.

[3]. Erlina, IP \& Widyarti, ET 2013, 'Analisis Pengaruh Current Ratio, EPS, ROA, DER, dan Size Terhadap Initial Return Perusahaan Yang Melakukan IPO', Diponegoro Journal Of Management, vol. 2, no. 2, pp. $1-13$.

[4]. Fuady, M 2001, 'Pasar Modal Modern'. Buku Kesatu. Bandung: PT.Citra Aditya Bakti.

[5]. Herawati, A 2017, 'The Factors Affecting Initial Return on IPO Company in IDX 2007 - 2012', International Journal of Economic Perspectives, vol. 11, Issue 1, pp. 1499 - 1509.

[6]. Hermin, S \& Murhadi, WR 2015, 'Factors Affecting Underpricing In The Company That Does IPO In BEI Period 2004-2014', Manajemen \& Bisnis Berkala Ilmiah,vol. 14.2, no.10, pp. 228 - 237.

[7]. Kurniawan, B 2007, 'Analisis Pengaruh Variabel Keuangan dan Non Keuangan Terhadap Initial Return dan Return 7 Hari Setelah Initial Public Offerings (IPO)', Jurnal Ekonomi dan Bisnis Indonesia, vol. 13, no. 1 , pp. 21 - 30.

[8]. Lutfianto, AS 2013, 'Determinan Initial Return Saham Go Public Tahun 2006-2011', Jurnal Ilmu Manajemen, vol. 1, no.1, pp. 364 - 376.

[9]. Prawesti, L \& Indrasari, A 2014, 'Informasi Akuntansi dan Non Akuntansi Terhadap Initial Return Saham', Jurnal Akuntansi \& Investasi, vol. 15, no. 1, pp. $17-27$.

[10]. Rivandi, M 2017, 'Faktor Fundamental Sebagai Penentu Initial Return', Jurnal Benefita, vol. 2 no. 3, pp. 299 - 307.

[11]. Santoso, E \& Wuryani, E 2013, 'Analisis Pengaruh Kinerja Keuangan, Ukuran Perusahaan, Reputasi Underwriter Dan Reputasi Auditor Terhadap Initial Return', Jurnal Ilmu Manajemen, vol. 1, No. 4 Juli, pp. 1130 - 1141.

[12]. Song, S \& Tan, JS \& Yi, Y 2014, ‘ IPO Initial Returns in China: Underpricing or overvaluation?', China Journal of Accounting Research, vol. 1, no. 1, pp. 13 49.

[13]. Suyatmin, \& Sujadi 2006, 'Faktor-Faktor yang Mempengaruhi Underpricing pada Penawaran Umum Perdana di Bursa Efek Jakarta', Benefit: Jurnal Manajemen dan Bisnis, vol. 10, no. 1, pp. 11 - 32.

[14]. Syukur, M \& Fathoni, Azis \& T, Edward Gagah P 2018, 'The Influence Of Financial And Non Financial
Information On Return Initials In Companies That Conduct IPO In Indonesia Stock Exchange', Journal of Management, vol. 4, no. 4, pp. 1 - 16.

[15]. Thionita, V 2019, 'Definisi IPO (Initial Public Offering)', diakses pada 21 Oktober 2019, https://www.finansialku.com/definisi-ipo-initialpublic-offering.

[16]. Wareza, 2018, 'Rekor! Dalam Setahun Lebih 50 Perusahaan IPO pada 2018, diakses pada 02 September 2019, https://www.cnbcindonesia.com/market/20181109125 101-17-41373/rekor-dalam-setahun-lebih-50perusahaan-ipo-pada-2018.

[17]. Wasiuzzaman, S \& Young F.L.K 2018, 'Impact Of Disclosure Of Risk Factors On The Initial Returns Of Initial Public OfferingS (IPOs)', Accounting Research Journal, Vol. 31 No. 1, pp: . 46-62

[18]. Widyawati, G \& Juanda, B \& Andat, T 2019, 'The Factors Of Initial Return Related To IPO Companies On The Indonesia Stock Exchange', Journal of Consumer Sciences, vol. 4, no. 2, pp. 119 - 135.

[19]. Wiguna, IGNH \& Yadnaya, K 2015, 'Analisis FaktorFaktor Yang Memengaruhi Initial Return Pada Penawaran Saham Perdana', E-Jurnal Ekonomi dan Bisnis Universitas Udayana, vol. 4, no.12 pp: 921946.

[20]. Wiyono, BB 2001, 'Statistik Pendidikan: Buku Bahan Ajar Mata Kuliah Statistik', Malang: FIP UM.

[21]. Zuliardi, K \& Witiastuti, R.S, 2020, 'Financial and Non-Financial Information Influencing Initial Return of IPOs on the Indonesia Stock Exchange', Management Analysis Journal, vol. 9, no. 2, pp: 087 199. 